\title{
SANKSI PIDANA KERJA SOSIAL TERHADAP TINDAK PIDANA RINGAN SEBAGAI UPAYA PEMBAHARUAN HUKUM PIDANA NASIONAL
}

\author{
SOCIAL SERVICE AS SANCTION AGAINST MINOR CRIMINAL \\ OFFENSE IN THE ACT OF NATIONAL CRIMINAL LAW REFORM
}

\author{
Teafani Kaunang Slat \\ Program Studi Magister Ilmu Hukum Universitas Brawijaya \\ Jalan M.T. Haryono 169, Malang \\ e-mail: teafani.slat@yahoo.co.id
}

\begin{abstract}
: this study aims to evaluate the provisions related to social service crime in the draft criminal law (R-KUHP) in the act of national criminal law reform. The study uses a normative juridical with a statue approach. The urgency of social service as the main criminal sanction against minor offenses can be justified through a combined criminal theory. Social service appropriate in the case of minor criminal offenses because this criminal has the advantage, i.e., the criminal sanction is punitive and still maintaining that the perpetrator can reintegrate into the community. The provisions of social service in the R-KUHP are quite complete and comprehensive. But several things can be noted, i.e., the need for adjustments to several clauses in the R-KUHP related to the provisions of social service and assessment to test the defendant's readiness to work in the community needs to be more oriented towards community safety.

Keywords: social service, minor criminal offenses, national criminal law reform
\end{abstract}

\begin{abstract}
Abstrak: kajian ini bertujuan untuk mengevaluasi ketentuan-ketentuan terkait pidana kerja sosial di dalam R-KUHP sebagai upaya pembaharuan hukum pidana nasional. Metode yang digunakan pada penelitian ini adalah normatif yuridis berpendekatan perundang-undangan (statue approach). Urgensi diterapkannya pidana kerja sosial sebagai pidana pokok terhadap tindak pidana ringan dapat dijustifikasi melalui teori pemidanaan gabungan. Pidana kerja social tepat diterapkan dalam perkara tindak pidana ringan karena pidana ini memiliki manfaat agar suatu sanksi pidana bersifat punitive namun tetap menjaga agar pelaku kejahatan dapat berintegrasi kembali ke masyarakat. Pengaturan terkait pidana kerja sosial dalam R-KUHP secara keseluruhan sudah cukup lengkap dan komprehensif, namun terdapat beberapa hal yang dapat menjadi catatan: perlunya penyesuaian terhadap beberapa klausul dalam R-KUHP terkait ketentuan pidana kerja sosial dan assessment untuk menguji kesiapan terdakwa untuk bekerja dalam suatu komunitas masyarakat perlu lebih berorientasi kepada keselamatan masyarakat.
\end{abstract}

Kata Kunci: pidana kerja sosial, tindak pidana ringan, pembaharuan hukum pidana nasional

\section{PENDAHULUAN}

Peraturan perundang-undangan di Indonesia tidak memberikan batasan yang jelas dalam mendefinisikan tindak pidana ringan, akan tetapi tindak pidana ringan digolongkan sebagai tindak pidana yang termasuk dalam acara pemeriksaan ringan menurut Kitab Undang-Undang Hukum Acara Pidana (KUHAP). Pasal 205 ayat 1 KUHAP mengategorikan tindak pidana ringan sebagai tindak pidana yang diancam dengan pidana penjara atau kurungan paling 
lama tiga bulan dan atau denda sebanyakbanyaknya tujuh ribu lima ratus rupiah dan penghinaan ringan. Dengan kata lain, tindak pidana yang menimbulkan kerugian kecil dan bersifat ringan disebut dengan tindak pidana ringan. Mahkamah Agung menerbitkan Peraturan Mahkamah Agung Nomor 2 Tahun 2012 tentang Penyesuaian Batasan Tindak Pidana Ringan dan Jumlah Denda dalam Kitab Undang-Undang Hukum Pidana yang ditujukan terhadap beberapa tindak pidana yang bersifat ringan. Pemberlakuan Peraturan Mahkamah Agung Nomor 2 Tahun 2012 tentang Penyesuaian Batasan Tindak Pidana Ringan dan Jumlah Denda dalam Kitab Undang-Undang Hukum Pidana tersebut ditujukan agar kasus tindak pidana ringan tidak diperlakukan sebagaimana halnya tindak pidana biasa.

Ketentuan tersebut mensyaratkan agar nilai barang yang menjadi objek dalam tindak pidana ringan harus memenuhi standar minimum agar dapat diperiksa melalui acara pemeriksaan cepat. Batasan nilai kerugian dalam kasus tindak pidana ringan yang sebelumnya berjumlah Rp250,00 (dua ratus lima puluh rupiah) kemudian diubah menjadi Rp2.500.000,00 (dua juta lima ratus rupiah) melalui peraturan tersebut. Selain itu, peraturan ini telah memberikan parameter terkait batasan nilai kerugian agar kasus tindak pidana ringan diperiksa melalui acara pemeriksaan cepat. Permasalahannya, penjatuhan pidananya masih mengacu kepada ketentuan hukum materiel yang ada dalam Kitab UndangUndang Hukum Pidana. Sanksi pidana yang diancamkan kepada tindak pidana ringan tersebut juga masih berupa pidana penjara jangka pendek.

Pidana penjara jangka pendek membawa berbagai macam permasalahan dan dianggap kurang tepat untuk diterapkan di dalam kasus tindak pidana ringan. Permasalahan saat ini muncul terkait dengan jumlah narapidana yang jauh melebihi kapasitas dari lembaga pemasyarakatan (over capacity) yang sebagian besar narapidana tersebut adalah pelaku tindak pidana minor dan non kekerasan (Mulyani, 2016). Posisi lembaga pemasyarakatan ialah merehabilitasi dan meresosialisasi pelaku tindak pidana dalam kerangka pengendalian dan pencegahan kejahatan (Situmorang, 2019). Tugas tersebut tidak boleh hanya dibebankan kepada lembaga pemasyarakatan, mengingat peran lembaga pemasyarakatan sebagai salah satu bagian dari sistem peradilan pidana.

Pidana pemenjaraan juga mendapatkan banyak kritik dari sudut kebijakan kriminal terhadap pidana pemenjaraan disebabkan antara lain terjadinya realitas di lapangan bahwa dengan dijatuhkannya pidana penjara tidak menjadikan pelaku menjadi lebih baik, namun semakin meningkat kejahatannya (Wibawa, 2017). Pidana penjara juga dapat mengakibatkan adanya perampasan terhadap kehidupan seksual yang normal, narapidana yang kehilangan pekerjaannya sehingga hal tersebut berdampak serius terhadap kehidupan sosial ekonominya, pandangan buruk bagi narapidana setelah menjalankan hukuman dapat mempersulit upaya reintegrasi sosial ke masyarakat, dan terjadinya degradasi dan penurunan derajat harga diri manusia yang disebabkan dari pengalaman hidup selama berada di dalam penjara. Penerapan sanksi pidana juga sebaiknya bersifat ultimum remedium atau alat terakhir dalam upaya penegakan hukum (Wibawa, 2017). Berdasarkan hal-hal tersebut, timbul wacana untuk memberlakukan sanksi lain selain pidana penjara jangka pendek terhadap tindak pidana ringan, yaitu berupa sanksi pidana kerja sosial atau community service.

Sanksi pidana kerja sosial dapat memberikan manfaat berupa kesempatan bagi pelaku untuk merehabilitasi diri ke dalam kehidupan bermasyarakat. Community service dapat bersifat menghukum (punitive) sekaligus merehabilitasi terdakwa (Muladi, 2018). Hukuman ini dapat berkontribusi terhadap peningkatan rasa percaya diri 
pelaku kejahatan, membuat pelaku kejahatan melakukan kegiatan yang bersifat positif, mencegah adanya isolasi terhadap pelaku kejahatan dari masyarakat, dan sekaligus memberikan manfaat terhadap masyarakat. Tuntutan akan adanya pembaharuan terhadap hukum pidana nasional berusaha dijawab dengan mulai dicantumkannya pidana kerja sosial (community service) sebagai salah satu pidana pokok dalam Rancangan Kitab Undang-Undang Hukum Pidana (R-KUHP) (Alarid, et al., 2008). Berdasarkan hal tersebut, tulisan ini akan membahas: (1) urgensi dari penerapan pidana kerja sosial sebagai pidana pokok terhadap tindak pidana ringan sebagai upaya pembaharuan hukum pidana nasional, dan (2) bentuk ideal dari pidana kerja sosial.

\section{METODE}

Penelitian ini menggunakan jenis penelitian yuridis normatif. Penelaahan kritis dan mendalam dilakukan terhadap bahan-bahan pustaka dan dokumen-dokumen hukum yang relevan dengan permasalahan hukum yang dikaji. Bahan hukum primer yang digunakan pada penelitian ini adalah Kitab Undang-Undang Hukum Pidana (KUHP), Rancangan Kitab Undang-Undang Hukum Pidana (R-KUHP), dan Peraturan Mahkamah Agung Nomor 2 Tahun 2012 tentang Penyesuaian Batasan Tindak Pidana Ringan dan Jumlah Denda dalam Kitab Undang-Undang Hukum Pidana.

\section{HASIL DAN PEMBAHASAN}

\section{Pembaharuan Hukum Pidana Nasional melalui Penerapan Pidana Kerja Sosial untuk Tindak Pidana Ringan}

\section{Urgensi dari Penerapan Pidana Kerja Sosial sebagai Pidana Pokok terhadap Tindak Pidana Ringan Ditinjau dari Filosofi Pemidanaan}

Tindak pidana ringan dapat dikategorikan sebagai kejahatan yang diatur dalam buku
ke-II tentang kejahatan. Definisi mengenai tindak pidana ringan tidak dapat ditemukan dalam KUHP. Pengertian mengenai tindak pidana ringan dapat ditemukan dalam KUHAP sebagai ketentuan hukum pidana formal dari KUHP. Pasal 205 ayat (1) KUHAP mengatur mengenai definisi tindak pidana ringan yaitu sebuah perkara yang ancaman pidananya berupa penjara atau kurungan paling lama tiga bulan dan atau denda paling banyak tujuh ribu lima ratus rupiah, serta pemeriksaannya dilakukan melalui acara pemeriksaan cepat.

Pasal-pasal yang dikategorikan sebagai tindak pidana ringan dalam Buku ke-II tentang kejahatan memiliki satu kesamaan, yakni adanya batasan kerugian dari kejahatan yang telah dilakukan. Batasan tersebut menyebutkan bahwa nilai kerugian yang diakibatkan tindak pidana tersebut tidak melebihi dari Rp25,00. Mahkamah Agung kemudian meningkatkan batas nilai kerugian menjadi Rp2.500.000,00 melalui Peraturan Mahkamah Agung Republik Indonesia Nomor 2 Tahun 2012 tentang Penyesuaian Batasan Tindak Pidana Ringan dan Jumlah Denda dalam KUHP.

Peraturan tersebut tetap merujuk kepada ketentuan hukum materiel dalam KUHP dan hukum formal KUHAP sebagai landasan hukumnya. Artinya, tindak pidana yang memenuhi ketentuan pasal tindak pidana ringan tetap akan dipidana dengan pidana pokok sebagaimana yang diatur dalam KUHP. Pidana penjara jangka pendek adalah pidana pokok yang digunakan dalam kasus tindak pidana ringan. Peraturan Mahkamah Agung Republik Indonesia Nomor 02 Tahun 2012 tentang Penyesuaian Batasan Tindak Pidana Ringan dan Jumlah Denda dalam KUHP hanya memberikan batasan (threshold) terhadap pengategorian jenis-jenis tindak pidana, namun tidak memberikan kepastian hukum terkait penjatuhan pidana mengingat sifat dari peraturan tersebut yang tidak mengikat secara hukum. Maka dari itu, tindak pidana ringan tetap dijatuhi pidana 
penjara jangka pendek sebagai balasan atas kejahatannya.

Berdasarkan filosofi pemidanaan, pidana pemenjaraan menjadi salah satu tujuan utama dari teori absolut. Teori absolut mengedepankan pembalasan sebagai tujuan utama diberlakukannya pidana. Teori ini berpegang pada prinsip "pidana untuk pidana", dan menitikberatkan kepada terjadinya kejahatan sebagai dasar pembenaran terhadap suatu pemidanaan (Kartanegara, 1986). Seiring berjalannya waktu, teori absolut banyak mendapatkan kritik dari para ahli hukum. Hal tersebut disebabkan karena penitikberatan pemidanaan atas kejahatan akan mengesampingkan nilainilai kemanusiaan (Nawawi, 1992). Teori absolut juga semata-mata bertujuan untuk memidanakan dan bukan sebagai alat penanggulangan kejahatan. Peninjauan terhadap justifikasi terkait sanksi pidana penjara jangka pendek terhadap tindak pidana ringan harus dilakukan dengan mendasarkan kepada teori pemidanaan yang lain. Ahliahli hukum yang melakukan kritik terhadap teori absolut kemudian memperkenalkan teori baru yakni teori relatif. Menurut Parker teori tersebut menyatakan bahwa penjatuhan pidana bukan sekedar untuk melakukan pembalasan atau pengimbalan (Hikmawati, 2016). Pembalasan itu sendiri tidak mempunyai nilai melainkan hanya sebagai sarana untuk melindungi kepentingan masyarakat.

Teori relatif dapat memberikan justifikasi penjatuhan pidana penjara jangka pendek terhadap tindak pidana sosial, namun teori ini juga memiliki beberapa kekurangan. Kekurangan-kekurangan tersebut antara lain: (a) pemidanaan yang didasarkan sebagai upaya untuk menakut-nakuti dapat menimbulkan ketidakadilan, (b) apabila tujuan dari pemidanaan adalah untuk semata-mata kebaikan dari pelaku, maka akan muncul rasa ketidakpuasan dari masyarakat yang merasa terabaikan, dan (c) tujuan pemidanaan untuk mencegah kejahatan dengan cara menakut-nakuti publik pada praktiknya akan sulit untuk diterapkan (Ilyas, 2012).

Teori relatif banyak mendapatkan kritik karena minimnya pertimbangan terhadap berat ringannya kejahatan yang dilakukan pelaku terhadap penjatuhan pidana. Berbeda dengan teori absolut yang menitikberatkan pembalasan terhadap setiap kejahatan, teori relatif berfokus kepada penjatuhan pidana di hadapan publik agar pidana tersebut dapat menjadi alat pencegah kejahatan di masyarakat. Agar pemidanaan dapat menakut-nakuti masyarakat, tindak pidana yang sifatnya ringan juga dapat dijatuhi hukuman berat.

Pada intinya, baik teori absolut dan teori relatif tidak dapat menjawab berbagai macam permasalahan yang dapat ditimbulkan dari diberlakukannya pidana penjara jangka pendek dalam kasus tindak pidana ringan. Teori relatif juga mengakibatkan penjatuhan pidana yang tidak sesuai proporsinya. Pidana pemenjaraan yang berlebihan dapat membawa permasalahan terutama terkait prison overcrowding atau kondisi kapasitas lembaga pemasyarakatan telah melebihi batas dan para terpidana hidup di dalam kondisi lembaga pemasyarakatan yang kurang memadai. Dampak kepadatan juga terjadi pada kualitas gizi, sanitasi, kegiatan tahanan, pelayanan kesehatan, dan perawatan bagi kelompok rentan. Lembaga pemasyarakatan juga dapat bergeser fungsinya menjadi sarana para pelaku kejahatan ringan mempelajari metode-metode kejahatan baru dari pelaku kejahatan yang sifatnya lebih berat (UNODC, 2013).

Berdasarkan kekurangan yang ada di dalam teori absolut dan teori relatif, para ahli mulai mengemukakan teori baru yang disebut dengan teori gabungan. Teori gabungan menganggap bahwa pemidanaan terhadap kejahatan diperlukan sebagai upaya pembalasan terhadap kerusakan yang telah terjadi. Kartanegara menjelaskan bahwa pembalasan yang dimaksudkan dalam teori 
gabungan tidak semata-mata untuk alasan pemuasan terhadap rasa keadilan (Hikmawati, 2016). Pembalasan tersebut diharuskan dilakukan dalam suatu batasan-batasan tertentu, yakni pembalasan tersebut tidak boleh melebihi beban kejahatan yang telah dilakukan. Hal tersebut berarti, pidana yang dijatuhkan tidak boleh melebihi proporsi yang telah ditentukan (Chazawi, 2002).

Pemidanaan berdasarkan teori gabungan menuntut adanya suatu pembaharuan terhadap sistem pemidanaan. Teori gabungan menuntut adanya sistem pemidanaan yang dapat memberikan pembalasan yang adil sesuai dengan proporsi kejahatan, sekaligus dapat menjawab permasalahan yang ditimbulkan dari pemidanaan jangka pendek terhadap kasus tindak pidana ringan (Purnomo, 1986).

Berdasarkan latar belakang tersebut, muncul wacana untuk membentuk sistem pemidanaan baru yakni pidana kerja sosial. Pidana kerja sosial merupakan jenis sanksi pidana yang menghukum terpidana dengan cara memberikan alokasi waktu kerja sosial bagi pelaku kejahatan (Failin, 2017). Kerja sosial yang dimaksud dapat berupa kerja sosial di masyarakat seperti membersihkan jalan, mengecat tembok, maupun bekerja di panti jompo.

Sanksi pidana kerja sosial didasarkan pada teori gabungan akan mampu mereformasi sanksi pidana yang ada saat ini dan menjawab permasalahan yang tidak mampu diatasi dalam teori absolut maupun relatif karena pidana kerja sosial memiliki unsur-unsur yang dicita-citakan menurut teori absolut dan relatif (Purwadiyanto, 2015). Unsur pembalasan yang dituju dalam teori absolut terpenuhi dalam pidana ini karena pelaku kejahatan tetap mendapatkan balasan atas tindak pidana yang dilakukannya. Unsur pencegahan kejahatan dengan cara memberlakukan pidana di hadapan publik akan terpenuhi dengan dihukumnya pelaku kejahatan di depan umum dengan cara kerja sosial.

\section{Penerapan Pidana Kerja Sosial sebagai Pidana Pokok terhadap Tindak Pidana Ringan sebagai Bagian dari Kebijakan Hukum Pidana}

Kebijakan hukum berorientasi pada pemberlakuan peraturan perundang-undangan yang diidealkan menurut masyarakat, serta dapat mengatasi isu-isu hukum yang sedang terjadi. Pidana pemenjaraan terhadap tindak pidana ringan juga tidak dapat dijustifikasi melalui teori pemidanaan, yakni teori gabungan. Teori gabungan sendiri menuntut adanya suatu pembaharuan sistem pemidanaan terhadap tindak pidana ringan. Pembaharuan tersebut hanya dapat dilakukan melalui suatu pelaksanaan kebijakan hukum pidana atau politik hukum pidana. Pidana kerja sosial menjadi salah satu solusi yang dapat diimplementasikan melalui kebijakan hukum pidana untuk mengatasi permasalahanpermasalahan yang tidak dapat diselesaikan melalui pidana pemenjaraan.

Kebijakan hukum yang baik adalah kebijakan hukum yang berkemanfaatan. Penilaian terkait manfaat suatu kebijakan hukum dapat didasarkan pada teori-teori kemanfaatan. Bentham mengemukakan bahwa dasar paling objektif untuk menilai baik buruknya suatu kebijakan adalah dengan melihat suatu kebijakan atau tindakan tersebut membawa dapat atau tidak dapat membawa manfaat atau hasil yang berguna, atau sebaliknya malah menimbulkan kerugian bagi orang-orang terkait (Kerap, 1998). Tujuan hukum adalah kesejahteraan sebesarbesarnya bagi seluruh rakyat, sedangkan evaluasi hukum dilakukan berdasarkan akibat-akibat dari proses penerapan hukum. Berdasarkan orientasi tersebut, maka isi hukum adalah ketentuan tentang pengaturan penciptaan kesejahteraan negara (Rasjidi \& Putra, 1993).

Sebelum pidana kerja sosial dapat diterapkan, perlu dilakukan suatu eksaminasi mendalam terkait dengan manfaat dari diberlakukannya kebijakan hukum berupa 
pidana kerja sosial terhadap tindak pidana ringan. Bertolak dari ajaran utilitarian Bentham, hukum ditujukan untuk sebesarbesarnya kesejahteraan masyarakat (Fios, 2012). Penerapan pidana kerja sosial dapat memenuhi aspek tersebut karenak banyak pihak yang dapat menerima manfaat dari kebijakan ini. Pidana penjara jangka pendek yang diterapkan dalam kasus tindak pidana ringan hanya memberi manfaat jangka pendek berupa rasa aman dan pembalasan yang didapatkan oleh masyarakat dengan dirampasnya kemerdekaan pelaku kejahatan oleh lembaga pemasyarakatan. Apabila dilihat dari perspektif solusi jangka panjang (long term solution), hal ini tidak efektif karena pemenjaraan tidak dapat mencegah terjadinya kejahatan yang baru dan tidak memenuhi rasa keadilan pelaku tindak pidana yang sifatnya ringan.

Di lain sisi, pidana kerja sosial dapat bermanfaat bagi banyak pihak. Pelaku kejahatan dapat menerima hukuman dalam proporsi yang wajar sesuai dengan kesalahan, sekaligus dapat belajar berintegrasi kembali ke dalam masyarakat melalui penebusan kesalahan dengan cara bekerja di masyarakat. Komunitas sekitar pelaku melakukan hukumannya juga dapat menerima manfaat sebesar-besarnya karena pelaku akan bekerja secara gratis untuk membantu masyarakat (Failin, 2017). Masyarakat dapat merasakan kepuasan dari pembalasan terhadap kejahatan yang telah dilakukan oleh pelaku, sekaligus terbantu dengan hasil kerja yang telah dihasilkan dari sanksi pidana yang dijalaninya. Menurut perspektif pencegahan kejahatan, pemidanaan ini juga dapat secara efektif menanggulangi kejahatan karena sifat dari hukuman ini dilaksanakan di muka publik. Pelaku dapat menyadari kesalahannya karena merasa malu atas kejahatan yang dilakukannya. Keadilan menjadi salah satu tujuan dari suatu kebijakan hukum, namun daya guna dan kemanfaatan dari kebijakan tersebut menjadi salah satu unsur penting dalam pemberlakuannya. Hukum harus dapat menjawab tantangan-tantangan yang baru dalam dinamika hubungan antar manusia yang tentunya selalu berubah sesuai waktu, sehingga politik hukum nasional yang sistematis dan terencana menjadi suatu urgensi. Efektifitas dari suatu kebijakan hukum sepenuhnya bergantung kepada manfaat yang ditawarkannya, sehingga seorang legislator perlu memproyeksikan manfaat dan kerugian dari diberlakukannya suatu kebijakan hukum.

Pidana kerja sosial merupakan suatu kebijakan hukum yang berkemanfaatan. Pemberlakuannya dapat memperbaharui sistem pemidanaan biasa yang sepenuhnya bergantung kepada lembaga pemasyarakatan dan pemenjaraan. Kedua hal tersebut tidak efektif lagi diterapkan dalam kasus-kasus kejahatan ringan, yang berkorelasi kepada tingginya angka residivis dan kurang terpenuhinya rasa keadilan di masyarakat. Pemberlakuan pidana kerja sosial akan dapat menanggulangi permasalahan-permasalahan yang tidak dapat dijawab oleh pidana penjara jangka pendek, serta membawa manfaatmanfaat lain baik bagi pelaku, masyarakat setempat, dan pemerintah.

\section{Bentuk Ideal dari Pidana Kerja Sosial sebagai Upaya Pembaharuan Hukum Pidana Nasional}

Perkembangan di dalam kehidupan masyarakat Indonesia menuntut adanya pembaharuan terhadap sistem hukum pidana nasional yang selama ini masih bergantung kepada kodifikasi undangundang hukum pidana warisan imperialisme Belanda. Pembangunan dalam bidang hukum, khususnya pembangunan atau pembaruan hukum pidana tidak hanya membangun lembaga-lembaga hukum, tetapi juga harus mencakup pembangunan substansi produkproduk hukum yang merupakan hasil suatu sistem hukum dalam bentuk peraturanperaturan hukum pidana (Rahardjo, 1980). 
Usaha terhadap pembaharuan hukum pidana telah dimulai sejak tahun 1963 dengan diadakannya Seminar Hukum Nasional I yang menuntut adanya pembaharuan terhadap hukum pidana nasional. Pada tahun berikutnya, diterbitkan Rancangan Kitab Undang-Undang Hukum Pidana (R-KUHP) untuk pertama kali yang terus berlangsung sampai sekarang, tetapi belum disahkan menjadi suatu undang-undang. Penyusunan R-KUHP adalah salah satu bentuk pembaharuan terhadap hukum pidana nasional yang bertujuan untuk meletakkan fondasi bagi sistem pidana Indonesia, serta untuk melaksanakan misi dekolonisasi KUHP peninggalan era kolonial. Materi hukum pidana dalam R-KUHP juga telah disesuaikan dengan perkembangan kehidupan bermasyarakat dan nilai-nilai universal yang dipegang teguh oleh masyarakat Indonesia, sebagaimana amanat dari Pancasila dan Undang-Undang Dasar Negara Republik Indonesia Tahun 1945.

Ditinjau dari sistematikanya, R-KUHP memiliki perbedaan yang sangat signifikan dengan KUHP saat ini. R-KUHP hanya terdiri atas dua buku, yakni Buku Kesatu tentang Ketentuan Umum yang terdiri atas enam bab dan 208 pasal (Pasal 1-208), dan Buku Kedua tentang Tindak Pidana yang terdiri atas 35 bab dan 519 pasal (Pasal 209-727). Dengan demikian, R-KUHP tidak membedakan antara kejahatan dan pelanggaran sebagaimana dalam KUHP dan menggantikannya dengan istilah yang lebih umum yaitu tindak pidana (Bahiej, 2004). Secara substansi, R-KUHP terdiri atas tiga pokok permasalahan, yakni tindak pidana, pertanggungjawaban pidana, serta pidana dan pemidanaan (Pohan, 2015). Salah satu perubahan paling signifikan terkait sistem pemidanaan di dalam R-KUHP adalah diberlakukannya pidana kerja sosial sebagai salah satu pidana pokok yang dapat dijatuhkan oleh hakim. Hal tersebut dinyatakan dalam Pasal 66 ayat 1 R-KUHP yang berbunyi sebagai berikut: (a) pidana penjara; (b) pidana tutupan; (c) pidana pengawasan; (d) pidana denda; dan (e) pidana kerja sosial.

Berbeda dengan KUHP sebelumnya, terdapat dua jenis pidana baru dalam R-KUHP ini, yakni pidana pengawasan dan pidana kerja sosial. Urutan jenis-jenis pidana pokok tersebut disesuaikan dengan berat ringannya tindak pidana yang dilakukan oleh terdakwa, sehingga hakim diberi kewenangan untuk memilih jenis pidana yang dianggap paling sesuai dengan tingkat kejahatan terdakwa.

Pidana kerja sosial dapat diberlakukan sebagai pengganti dari pidana denda. Hal tersebut dinyatakan dalam Pasal 85 ayat (1) R-KUHP yang menjelaskan pidana denda kategori I adalah pidana denda yang dijatuhkan dengan nominal tidak melebihi Rp10.000.000,00 (sepuluh juta rupiah). Berdasarkan ketentuan tersebut, apabila pidana denda tidak mungkin dilakukan, terdakwa dapat menggantinya dengan pidana kerja sosial.

Pidana kerja sosial dalam R-KUHP memang mendapatkan kedudukan sebagai salah satu jenis pidana pokok, namun pemberlakuannya masih sebatas alternatif di luar pidana pemenjaraan dan bergantung kepada putusan hakim. Hakim dalam pertimbangannya dapat menerapkan pidana kerja sosial sebagai pengganti pidana pemenjaraan apabila pidana penjara yang dijatuhkan tidak lebih dari enam bulan penjara. Pertimbangan tersebut harus didasarkan kepada beberapa hal seperti karakter terdakwa. Terkait dengan jangka waktu pelaksanaan pidana kerja sosial, terdapat beberapa pedoman yang diatur dalam R-KUHP, sebagaimana yang disebutkan dalam Pasal 88 ayat (4) dan ayat (6). Pidana kerja sosial dapat dijatuhkan dengan ketentuan paling lama 240 jam bagi terdakwa yang berusia di atas 18 tahun, serta dapat dilaksanakan dalam jangka waktu maksimal satu tahun. Hal ini tentunya akan sangat menguntungkan pelaku tindak pidana ringan karena pelaksanaan pidana kerja sosial akan memperhatikan 
jam kerja pelaku. Tindak pidana ringan umumnya dilatarbelakangi motif ekonomi, sehingga pelaku tindak pidana ringan tetap dapat mempertahankan mata pencahariannya sembari melaksanakan hukum pidananya.

R-KUHP juga mengatur sanksi bagi terdakwa yang dijatuhi pidana kerja sosial namun tidak melaksanakan hukuman tersebut dengan baik. Pelaku dapat dihukum agar mengulang pelaksanaan pidana kerja sosial, membayar denda, maupun menggantinya dengan pidana penjara. Pasal 88 ayat (7) R-KUHP mengatur tentang pelanggaran terhadap pidana kerja sosial sehingga pelanggaran terhadap pelaksanaan pidana kerja sosial dapat membawa konsekuensi yang serius bagi terdakwa. Hal tersebut ditujukan agar pelaksanaan pidana kerja sosial tetap membawa efek menghukum bagi terdakwa, namun juga mengedukasi terdakwa.

Secara keseluruhan, pengaturan terkait pidana kerja sosial dalam R-KUHP sudah cukup lengkap dan komprehensif. Terdapat beberapa hal yang perlu digarisbawahi dalam wacana pidana kerja sosial menurut R-KUHP di Indonesia. Hal tersebut terkait dengan bentuk pidana kerja sosial sebagai salah satu jenis pidana pokok menurut Pasal 66 ayat (1) R-KUHP. Meskipun pidana kerja sosial mendapatkan posisi sebagai pidana pokok dalam R-KUHP, pemberlakuannya masih berupa alternatif dari pidana pemenjaraan dan masih bergantung kepada pertimbangan hakim. Hakim dapat memberlakukan pidana kerja sosial sebagai pengganti apabila vonis yang dijatuhkan terhadap terdakwa tidak lebih dari enam bulan penjara. Akan tetapi, R-KUHP masih memuat permasalahan yang sama dengan Peraturan Mahkamah Agung Nomor 2 Tahun 2012 tentang Penyesuaian Batasan Tindak Pidana Ringan dan Jumlah Denda dalam Kitab UndangUndang Hukum Pidana yaitu hakim tidak terikat dengan ketentuan tersebut dan dapat terus menjatuhkan pidana pemenjaraan dalam kasus-kasus tindak pidana ringan.
R-KUHP juga telah mengatur terkait dengan assessment yang dilakukan terhadap terdakwa untuk menguji kesiapan terdakwa melakukan pidana kerja sosial di masyarakat. Terdapat beberapa klausul dalam assesment yang patut dipertanyakan, seperti klausul dalam Pasal 88 ayat (2) huruf (f) R-KUHP yang perlu mempertimbangkan keyakinan agama dan politik terdakwa. Tidak jelas korelasi antara keyakinan agama dan politik terdakwa dengan kemampuan terdakwa untuk melaksanakan pidana kerja sosial. Klausul ini sangat rentan dengan diskriminasi mengingat hakim dapat mempertimbangkan untuk tidak menjatuhkan pidana kerja sosial atas dasar keyakinan agama dan politik terdakwa.

Klausul lain yang belum jelas adalah penempatan terdakwa untuk melaksanakan pidana kerja sosial belum diatur di dalam R-KUHP. Pidana kerja sosial dapat berfungsi dengan maksimal apabila pelaksanaannya dilakukan secara tepat. Pengadilan dapat menempatkan terdakwa dalam suatu kerja sosial yang menuntut agar kemampuan terdakwa dapat bermanfaat untuk masyarakat luas. Contohnya, terdakwa yang memiliki kemampuan sepak bola yang baik dapat diperintahkan pengadilan untuk melaksanakan pidana kerja sosial dalam bentuk melatih klub sepak bola anak-anak secara sukarela. Pidana kerja sosial tersebut kemudian akan menjalankan fungsinya dengan menghukum terdakwa sekaligus memberikan rehabilitasi baginya. Masyarakat mendapatkan manfaat dari pidana kerja sosial dan pemerintah dapat menekan anggaran yang dialokasikan kepada lembaga pemasyarakatan.

\section{SIMPULAN}

Urgensi diterapkannya pidana kerja sosial sebagai pidana pokok terhadap tindak pidana ringan dapat dijustifikasi melalui teori pemidanaan gabungan. Pidana kerja sosial dirasa tepat diterapkan dalam perkara tindak pidana ringan karena pidana ini memiliki manfaat agar suatu sanksi pidana bersifat 
punitive namun tetap menjaga agar pelaku kejahatan dapat berintegrasi kembali ke masyarakat. Pengaturan terkait pidana kerja sosial dalam R-KUHP secara keseluruhan sudah cukup lengkap dan komprehensif, namun terdapat beberapa hal yang dapat menjadi catatan. Hal tersebut terkait dengan perlunya penyesuaian terhadap beberapa klausul dalam R-KUHP terkait ketentuan pidana kerja sosial. Klausul tersebut antara lain terkait dengan posisi pidana kerja sosial sebagai pidana pokok, namun dalam penerapannya masih sepenuhnya bergantung terhadap kebijakan hakim. Selain itu, assessment untuk menguji kesiapan terdakwa untuk bekerja dalam suatu komunitas masyarakat perlu lebih berorientasi kepada keselamatan masyarakat.

\section{DAFTAR RUJUKAN}

Alarid, L. F., Cromwell, P. F., \& Carmen, R. V. del. (2008). Community-Based Corrections. Belmont: Thomson Wadsworth.

Chazawi, A. (2002). Pelajaran Hukum Pidana Bagian I. Jakarta: Raja Grafindo Persada.

Failin. (2017). Sistem Pidana dan Pemidanaan di dalam Pembaharuan Hukum Pidana Indonesia? Jurnal Cendikia Hukum, 3(1), 14. https://doi.org/10.33760/ jch.v3i1.6

Fios, F. (2012). Keadilan Hukum Jeremy Bentham dan Relevansinya Bagi Praktik Hukum Kontemporer. Humaniora, 3(1), 299-309. journal.binus.ac.id

Hikmawati, P. (2016). Pidana Pengawasan sebagai Pengganti Pidana Bersyarat Menuju Keadilan Restoratif. Negara Hukum, 7(1), 71-88.

Ilyas, A. (2012). Asas-Asas Hukum Pidana: Memahami Tindak Pidana dan Pertanggungjawaban Pidana sebagai Syarat Pemidanaan. Yogyakarta: Mahakarya Rangkang.

Kartanegara, S. (1986). Hukum Pidana Kumpulan Kuliah, Bagian Satu. Jakarta: Ghalia Indonesia.
Kerap, S. (1998). Etika Bisnis Tuntunan dan Relevansinya. Yogyakarta: Kanisius.

Muladi. (2018). The Prospect of Alternative Sanctions in Indonesia. https://aic. gov.au/sites/default/files/publications/ proceedings/downloads/12-muladi.pdf

Mulyani, S. (2016). Penyelesaian Perkara Tindak Pidana Ringan Menurut Undang-Undang dalam Perspektif Restoratif Justice. Jurnal Penelitian Hukum De Jure, 16(3), 337-351.

Nawawi, B. (1992). Teori dan Kebijakan Pidana. Bandung: Alumni.

Pohan, A. (2015). Public Review RUU KUHP. https://antikorupsi.org/sites/ default/files/doc/Regulasi/RUU

Purnomo, B. (1986). Pelaksanaan Pidana Penjara Dengan Sistem Pemasyarakatan. Yogyakarta: Liberry.

Purwadiyanto, T. (2015). Analisis Pidana Kerja Sosial Dalam Hukum Positif Di Indonesia. Lex Administratum, 3(8), 158-169. https://ejournal.unsrat. ac.id/index.php/administratum/article/ view/10272

Rahardjo, S. (1980). Hukum dan Masyarakat. Bandung: Angkasa.

Rasjidi, L., \& Putra, I. B. W. (1993). Hukum Sebagai Suatu Sistem. Bandung: Remaja Rosdakarya.

Situmorang, V. H. (2019). Lembaga Pemasyarakatan Sebagai Bagian Dari Penegakan Hukum. 13(1). https:// doi.org/http://dx.doi.org/10.30641/ kebijakan.2019.V13.85-98

UNODC. (2013). Panduan tentang Strategi untuk Mengurangi Kepadatan di Penjara: Seri Pengadilan Pidana. New York. https://docplayer.info/378050Panduan-tentang-strategi-untukmengurangi-kepadatan-dalam-penjara. html

Wibawa, I. (2017). Pidana Kerja Sosial dan Restitusi Sebagai Alternatif Pidana Penjara dalam Pembaharuan Hukum Pidana Indonesia. Jurnal Media Hukum, 24(2), 108. 